\title{
THE ROLE OF ENTREPRENEURIAL ORIENTATION ON THE GLOBAL VEGETABLE SUPPLY CHAIN AND ON FARM PERFORMANCE IN WEST JAVA, INDONESIA
}

\author{
Nunung Kusnadi*)1, Etriya Etriya*), Yanti N. Muflikh*), Siti Jahroh**), and Herawati*) \\ *) Department of Agribusiness, Faculty of Economics and Management, Bogor Agricultural University \\ Kamper Road, Wing 2 Level 5, Dramaga Campus IPB 16680 \\ **) School of Business, Bogor Agricultural University \\ Pajajaran Road, Bogor 16151
}

\begin{abstract}
Global market provides opportunities for business owners to grow their business. However, to what extent farmers - as one of business owners - take benefits from the global markers remains unclear. This paper aims to investigate the impact of entrepreneurial orientation on farmers' involvement in global supply chain, in turn on farm performance. The data were gathered from a survey of 320 samples of vegetable farmers in three regions in West Java, Indonesia. Using PLS analysis, our findings demonstrate that farmers with higher entrepreneurial orientation (reflected by dimensions of innovativeness, proactiveness, risk taking, competitive aggressiveness, and autonomy), involve more in global supply chain, and gain higher farm performance. Ultimately, the more farmers involve in global supply chain, the higher their farm performance. Our findings provide an empirical support for the impact of entrepreneurial orientation on enabling farmers' ability to involve in broader supply chains beyond the domestic ones. As a consequence, farmers enjoy better farm performance.
\end{abstract}

Keywords: autonomy, competitive aggressiveness, entrepreneurial, risk taking, PLS

\begin{abstract}
Abstrak: Pasar global memberikan peluang bagi pelaku bisnis untuk mengembangkan bisnisnya. Tetapi, sejauh mana petani - selaku salah satu pelaku bisnis - memanfaatkan peluang dari pasar global masih belum jelas. Paper ini bertujuan untuk menginvestigasi dampak dari orientasi kewirausahaan pada keterlibatan petani di dalam rantai pasok global, dan dampak selanjutanya pada kinerja usaha. Data diambil dari survei pada 320 sampel petani sayur di tiga wilayah di Jawa Barat, Indonesia. Dengan menggunakan analisis PLS, hasil penelitian kami menunjukkan bahwa petani dengan orientati kewirausahaan yang lebih tinggi (direfleksikan oleh dimensi inovasi, proaktif, pengambilan risiko, aggresif berkompetisi, dan otonomi) lebih banyak terlibat dalam rantai pasok global, dan memperolah kinerja usaha lebih tinggi. Hasil penelitian kami memberikan dukungan empiris bahwa dampak orientasi kewirausahaan dalam memampukan petani untuk terlibat di rantai pasok yang lebih luas bahkan lebih jauh dari rantai pasok domesitk. Sebagai konsekuensi, petani menikmati kinerja usaha yang lebih baik.
\end{abstract}

Kata kunci: otonomi, agresif berkompetisi, kewirausahaan, pengambilan risiko, PLS

\footnotetext{
${ }^{1}$ Corresponding author:

Email: nunungkusnadi@gmail.com
} 


\section{INTRODUCTION}

Indonesia actively participates in global or regional markets, such as ASEAN-China Free Trade Area (ACFTA), ASEAN Free Trade Area (AFTA), and ASEAN Economic Community (AEC). These free trade agreements not only provide more opportunities but also create more competitions among (local and international) business actors, including actors in the vegetable subsector. The positive impact of these agreements is indicated by the growth of export volume of horticulture products by $0.97 \%$ per year exclusively, and by the growth of vegetables export volume by $13.50 \%$ per year (Statistics Indonesia, 2014).

Although the free trade agreement seems to give a positive a positive impact on the export performance of vegetables, the domestic markets are also threatened by the surge of the imported horticulture increasing by $1.63 \%$ per year, including imported vegetables that grow $16.90 \%$ per year (Statistics Indonesia, 2014). As a result, the growth of imported vegetables is higher when compared to the growth of exported vegetables. It may indicate that consumers prefer to buy imported vegetables, such as ones from China or Thailand, which show better appearance and relatively lower price than that of the local vegetables. Hence, these dynamic global markets challenge all business actors in the domestic markets including markets to optimally take the opportunities and effectively deal with possible threats.

Farmers are important actors in the vegetable sector. However, it remains unclear to what extent farmers especially smallholders engage in global markets and enjoy the opportunities shared in the markets (Kaplinsky, 2004). The literature inconclusively agrees with the critiques who propose that the global markets and the growth of modern markets provide more market opportunities for smallholders (Kaplinsky, 2004; van Dijk and Trienekens, 2011; Shalendra et al. 2013). The literature also recognizes the importance of entrepreneurship as a source of innovation to effectively engage in the dynamic competitive markets (Kaplinsky, 2000; Kaplinsky, 2004; Swanson, 2006; Amanor, 2009; Riisgaard et al. 2010). Building upon the concept of entrepreneurial orientation and supply chain, we aim to investigate the impact of entrepreneurial orientation on farmers' involvement in global supply chain and on farm performance, and in turn the impact of the farmers' involvement in global supply chain on farm performance.
This paper is organized as follows. In the next section, we present the methods for data collection, model specification, hypotheses, and data analysis. In this section, we also provide the structural model incorporating entrepreneurial orientation, global supply chain, and farm performance. Next, we present the results of descriptive statistics and hypothesis tests and discuss the results. We conclude the paper by summarizing the main results including limitations, directions for future studies, and recommendations for policy makers.

\section{METHODS}

Our study was conducted in West Java, one of the largest vegetable producing areas in Indonesia. This area is close to big cities like Jakarta and Bandung, where modern markets like supermarkets and export markets are growing. On the other hand, traditional markets for vegetables are available in and around West Java, thus farmers have many options to choose the buyers of their products. Closeness to modern markets (local and international) or traditional markets makes farmers in West Java have high possibility to be exposed to new information and business opportunities. Hence, this setting of West Java makes it relevant for the study of global value chain in relation to entrepreneurial orientation and farm performance.

The data were gathered in three regions of West Java: Bandung, Garut, and Cianjur from May to September 2016. These three regions were chosen based on the criteria of large variations in market options and in agricultural technologies. Data from Statistic Indonesia listed 29,247 farmers producing vegetables in West Java in 2013. After confirming the list to the local government and extension agents, we administered farmers whom we used as our sampling frame for the survey. We randomly chose 320 farmers as the samples for further analyses. The survey was conducted using face-to-face interviews.

\section{Model specification}

The literature defines entrepreneurial orientation as to a set of organizational activities in strategic-making process including practices, methods, and styles to explore and exploit new opportunities (Miller, 1983; Lumpkin and Dess, 1996; Stevenson and Jarillo, 2007). Entrepreneurial orientation consists of five dimensions, 
namely, innovativeness, proactiveness, risk taking, competitive aggressiveness, and autonomy (Lumpkin and Dess, 1996).

Adapted from the literature of entrepreneurial orientation, this paper refers innovativeness as to a farmer's proclivity to involve in activities developing new or improved products or technology processes. Proactiveness is the effort of farmers to anticipate future demand by taking initiatives and pioneering over the competitors. Risk taking reflects braveness to take considerable risks to involve in new activities by investing the large amount of important resources. Competitive aggressiveness refers to activities aiming to be superior over competitors by beating the competitors or securing current firm's position in the market. Autonomy refers to the independency of a firm or people in the firm to take entrepreneurial decisions, from ideas to completions (Lumpkin and Dess, 1996).

Entrepreneurial orientation helps firms/farms to face the changes by being proactive in anticipating future demand, fearless in taking considerable risks, and innovative in introducing new products (Lumpkin and Dess, 1996). In this paper, entrepreneurial orientation is expected to improve farm performance (Grande et al. 2011, Verhees et al. 2012). Therefore, entrepreneurial orientation enables firms or farms to achieve better performance by being adaptive in facing environment changes.

Entrepreneurial orientation is associated with organizational knowledge including market knowledge (Wiklund and Shepherd, 2005). Knowledge allows firms to anticipate opportunities caused by the environmental changes (Cohen and Levinthal, 1990). Furthermore, knowledge about markets may enable firms to explore and exploit opportunities, and ultimately may improve firm performance for several reasons: (1) understanding customer problems helps firms realize opportunities, (2) market knowledge allows firms to find market value of technological knowledge, (3) interaction with customers as users may facilitate firms to discover opportunities by creating innovations that meet customers' needs (Von Hippel, 1986; Wiklund and Shepherd, 2005). Accordingly, entrepreneurial orientation is likely to enhance firms' ability in accumulating market knowledge especially orientation towards global supply chain, and in turn orientation towards global supply chain is likely to improve firm or farm performance.
Modern markets including global markets provide more market opportunities for farmers especially in supply chain. Supply chain management supports business strategies of firms along the chains to jointly involve in creative and innovative activities (Dunne, 2001). A previous study suggests that farmers' entrepreneurial behavior plays an important role in supply-chain performance (Velde et al. 2006). In addition, another study shows that entrepreneurial orientation contributes to enhance farm performance (Grande et al. 2011).

Although the concept of global supply chain involves diverse actors of the chain, this paper focuses on global supply chain from the farmers' perspective as the primary actor in the chain. For the case of vegetables, the global supply chain consists of actors, such as farmers as vegetable producers/growers, middle men, exporters, and retailers (Sunanto, 2013). Because vegetables in Indonesia are mainly produced by smallholders, they become important actors for the global supply chain of vegetables. Vegetable farmers deal with actors in the global supply chain with different types of transaction. Most farmers independently sell their products without any formal contractual agreement with buyers (e.g. to middle men), but few farmers already have the agreement with buyers (e.g. vegetable suppliers for modern markets/ exporters) (Sahara and Gyau, 2014). We focus on the relationships between farmers and buyers who directly buy farmers' products, especially with buyers/actors that are linked with export or import markets.

We categorize farmers involving in the global supply chain if they make transactions or have contractual agreement with actors who involve in the global supply chain of vegetables, such as exporters or modern food retails (which provide both local and imported vegetables). As suppliers in modern food retails, vegetable farmers face a competition with suppliers of imported vegetables (e.g. from China or Thailand) in terms of quality, quantity, varieties, and prices. Therefore, these farmers have to provide the buyers (who are linked with export or import markets) products with certain criteria, such as vegetables with a premium quality on certain quantities (Natawidjaja et al. 2007).

This paper elaborates global supply chain and farm performance as dependent variables, and entrepreneurial orientation was the independent variable. Our structural model incorporates both reflective and formative construct to present the variables (Figure 1.) 
We argue that farmers who have a higher degree of entrepreneurial orientation will have more involvement in global supply chain; and in turn the farmers will participate in modern markets including global markets, and ultimately enhance farm performance. Our related hypotheses:

H1: Farmers with higher entrepreneurial orientation will have more involvement in global supply chains.

$\mathrm{H} 2$ : Farmers with higher entrepreneurial orientation will have better farm performance.

H3: Farmers who have more involvement towards global supply chains will have better farm performance.

To test the hypotheses, the data were analyzed with Partial Least Squares (PLS) using the open-access statistical software R with PLSPM Package (Sanchez at al. 2017).

Independent variables

Entrepreneurial orientation. Entrepreneurial orientation was operationalized with five dimensions, namely: innovativeness, proactiveness, risk taking, competitive aggressiveness, and autonomy (Lumpkin and Dess 1996). Each dimension was a reflective construct that was measured by three indicators, where each indicator was calculated as the aggregation of seven sub-indicators. The value of each score ranges from 0 to 7 . We used cumulative scores to measure these dimensions to reduce the potential of self-reporting bias, which usually occurs in perceptual measures (Andersen, 2010). The reliability of the constructs were shown by the scores of Cronbah's Alpha (CA), DG rho, the close range of 1st and 2nd Eigen value (eig).
Proactiveness. Proactiveness was measured as the extent to which farmers take initiatives, being the first introducing new products or technologies, and being a reference of other farmers (Covin and Slevin, 1989; Grande et al. 2011). This construct shows sufficient reliability $(\mathrm{CA}=0.63 ; \mathrm{DG}$ rho $=0.80 ; 1 \mathrm{st}$ eig $=1.73$; 2nd eig=0.75).

Innovativeness. Innovativeness was operationalized as intensity in R\&D activities, number of new products, and the degree of technological changes (Covin and Slevin, 1989). This construct shows good reliability $(\mathrm{CA}=0.82 ; \mathrm{DG}$ rho $=0.89 ; 1$ st eig $=2.20 ; 2$ nd eig $=$ $0.54)$.

Risk taking. Risk taking was calculated as an eagerness to involve in high-risk activities with unknown returns, braveness in achieving goals, and efforts to seek new opportunities (Covin and Slevin, 1989). This construct demonstrates sufficient reliability $(\mathrm{CA}=0.66$; $\mathrm{DG}$ rho= $0.81 ; 1$ st eig $=1.73 ; 2$ nd eig $=0.73)$.

Competitive aggressiveness. Competitive aggressiveness was measured as a tendency to monitor the environment and competitors, being aggressive over competitors, and react to competitive threats (Hughes and Morgan, 2007; Lumpkin and Dess, 2001). This construct posits good reliability $(\mathrm{CA}=0.82$; DG rho $=0.89 ; 1$ st eig $=2.22 ; 2$ nd eig $=0.52$ ).

Autonomy. Autonomy was operationalized as independency in modifying business, freedom in making decisions and taking actions, and being the knowledge leader (Miller, 1983; Hughes and Morgan, 2007). This construct demonstrates sufficient reliability $(\mathrm{CA}=0.62 ; \mathrm{DG}$ rho $=0.80 ; 1$ st eig $=1.84 ; 2$ nd eig $=$ $0.95)$.

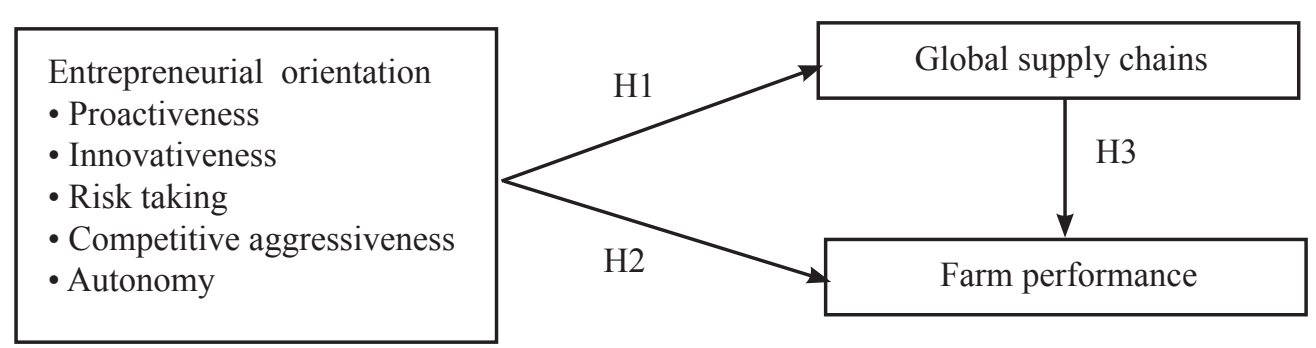

Figure 1. Model specification 


\section{Dependent variables}

This paper used two constructs as dependent variables, i.e. farmers' involvement towards global supply chains and farm performance. Meanwhile, five dimensions of entrepreneurial orientation act as independent variables, and the relationships of these two constructs are developed to test the three hypotheses.

Farmers' involvement towards global supply chain. This construct is a reflective one, which was measured by five indicators, which are calculated as scores: (1) Farmer market bargaining position measuring the power of farmers in controlling the transaction process, (2) farmer market orientation measuring the farmer sensitivity toward consumer needs, (3) farmers knowledge concerning export markets, (4) import markets, and (5) domestic markets for their products. This construct posits good reliability $(\mathrm{CA}=0.79$; DG rho $=0.85 ; 1$ st eig $=2.74 ; 2$ nd eig $=0.84$ ).

Farm performance. Farm performance was measured using objective measures to avoid the potential of common method bias (Andersén, 2010). This construct is a formative one, which was measured by eight indicators: (1) Number of market functions conducted by farmers at farm level, (2) buyer types, (3) value of vegetables sold in a year, (4) farm size, (5) value of non-land farm assets, (6) number of vegetable types produced in a year, (7) cropping intensity within a year, and (8) vegetables pricing. In addition, buyer types were measured by the degree of market institutions involved in global supply chains, and vegetable pricing was measured by the degree of farmers' bargaining power in determining price of their products. We expect that the more powerful the farmers in determining prices, the higher the score of vegetable pricing.

\section{RESULTS}

The descriptive statistics show that the size of vegetable farms are mainly small (1.90 hectares on average), but they yield relatively high gross farm income (Table 1) compared to other crops, such as rice farms. Most farms produce various types of vegetables, in which the cropping intensity is more than $100 \%$ per year. Some farmers produce vegetables for domestic/traditional markets, whereas some others produce high-value vegetables dedicated for export markets or modern food retails, such as sweet peppers or French beans. Compared to farmers of other crops like rice, vegetable farmers seem to have more freedom to decide what types of vegetable to be produced and what markets to deliver the products, either domestic or global markets.

Farmers' involvement in global supply chain can be seen from market functions and transactions with export markets or modern food retails. We found that the most important market functions conducted by farmers to be involved in global supply chain are sorting, grading, and packaging. In indicates that these farmers are concern on requirements to provide especially global markets with high-quality vegetables. We found that 66 $\%$ of farmers in our samples are directly or indirectly involved in the global supply chain of vegetables (Table $1)$.

Generally, vegetable farmers are free to choose marketing channels that provide them with good prices. Their decisions are mainly based on sales and payment procedures. Most farmers prefer pricing method either by buyer-seller negotiations ( $47 \%$ ) or based on current market prices (40\%) (Table 1). It indicates that market structure faced by vegetable farmers tends to be perfect competition. It seems that although vegetable farmers are mainly smallholders, they have bargaining position in the global supply chain of vegetables.

Path coefficients of structural model are presented in Figure 2. The results confirm hypothesis 1 claiming that farmers with a higher degree of entrepreneurial orientation will involve more in global supply chain, which were explained by all dimensions of entrepreneurial orientation (proactiveness: $\beta=0.24, p \leq$ 0.01 ; innovativeness: $\beta=0.22, p \leq 0.01$; risk taking: $\beta=$ $0.14, p \leq 0.01$; competitive aggressiveness: $\beta=0.22$, $p$ $\leq 0.01$; autonomy: $\beta=0.16, p \leq 0.01)$. Next, the results partly confirm hypothesis 2 expecting that farmers with a higher degree of entrepreneurial orientation will have better farm performance, which was explained only by proactiveness dimension $(\beta=0.20, p \leq 0.01)$. Finally, the results also confirm hypothesis 3 arguing that farmers who involve in global supply chains will have better farm performance. Our results; thus, prove the formulated hypotheses. 
Table 1. Characteristics of vegetable farmers and marketing chains

\begin{tabular}{lcc}
\hline Characteristics & Number of Farmers & $\%$ \\
\hline Farm Size & & \\
$<0.5$ ha & 129 & 40.31 \\
$0.5-1.0$ ha & 56 & 17.50 \\
$>1.0$ ha & 135 & 42.19 \\
Non-Land Assets (000,000 IDR) & & \\
$<100$ & 264 & 82.50 \\
$100-500$ & 41 & 12.81 \\
$>500$ & 15 & 4.69 \\
Value of Product Sold (000,000 IDR) & & \\
$<50$ & 61 & 19.06 \\
$50-100$ & 51 & 15.94 \\
$>100-200$ & 61 & 19.06 \\
$>200$ & 147 & 45.94 \\
Product Buyer & & \\
Local Traders & 210 & 65.63 \\
Cooperatives and modern institutions & 110 & 34.38 \\
Marketing Functions at the Farm Level & & \\
Sorting & 132 & 41.25 \\
Grading & 72 & 22.5 \\
Packaging & 194 & 60.625 \\
Price Determinant & & \\
Farmer & 7 & 2.19 \\
Buyer & 15 & 4.69 \\
Farmer and buyer & 151 & 47.19 \\
Market price & 128 & 5.94 \\
Others & 19 & \\
\hline & & \\
\hline & & \\
\hline
\end{tabular}

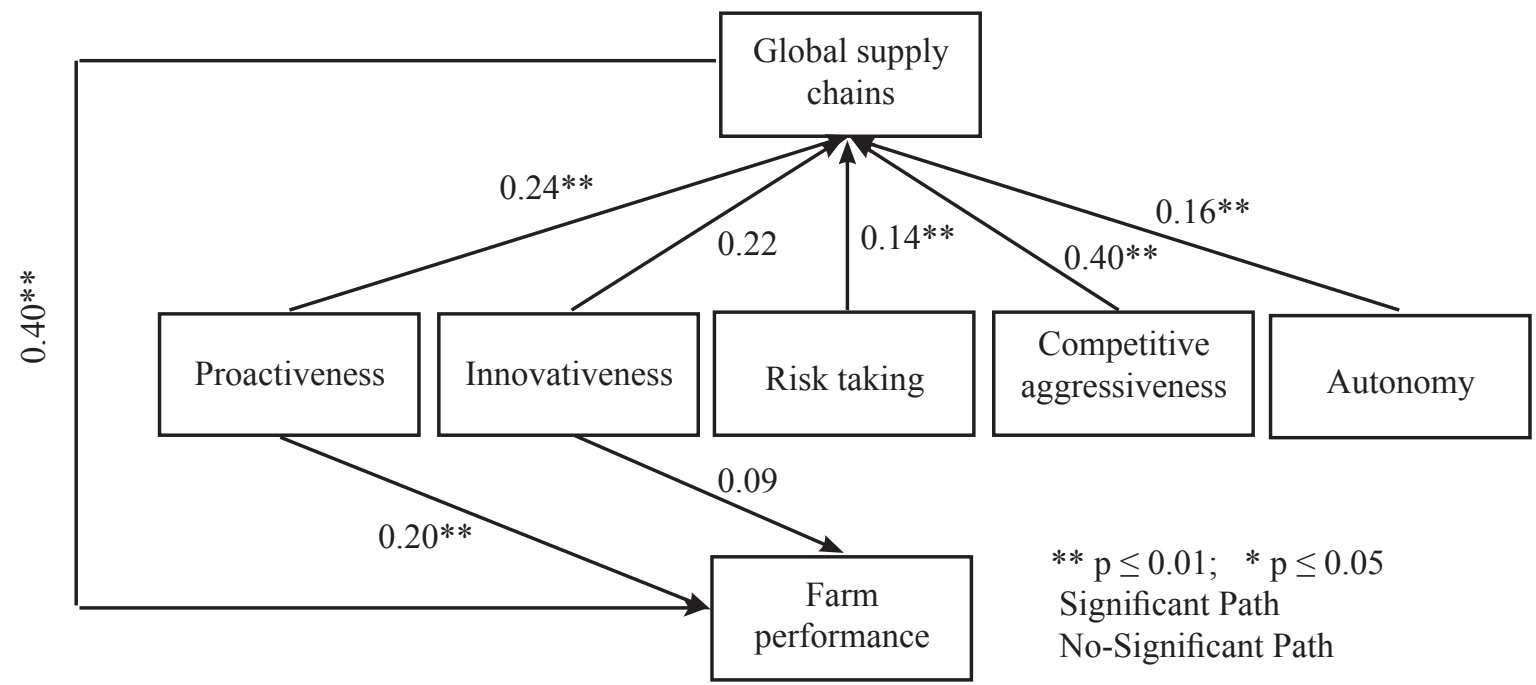

Figure 2. Results of the research model 
This paper aims to investigate the impact of entrepreneurial orientation on farmers' involvement in global supply chain and on farm performance, and the impact of farmers' involvement in global supply chain on farm performance. The results show that all dimensions of entrepreneurial orientation (i.e. proactiveness, innovativeness, risk taking, competitive aggressiveness, and autonomy) positively influence their involvement in the global supply chain of vegetables. It indicates that entrepreneurial orientation helps farmers especially smallholders to access and participate in global supply chains. Entrepreneurial orientation helps farmers to overcome obstacles in accessing global supply chains. For instance, the dimensions of proactiveness and innovativeness facilitate farmers in fulfilling (global) markets with high-quality vegetables. Although previous studies show that entrepreneurial orientation are mainly owned big companies or big farmers, our results show that entrepreneurial orientation is also important for smallholders. One may notice that entrepreneurial orientation matters for smallholders to access global supply chains if they produce highvalue crops. It may be because global supply chains prefer this type of crop (e.g. high-value vegetables) that makes smallholders have an opportunity to participate in this global supply chains.

Our results show that all dimensions of entrepreneurial orientation improve farmers' involvement in global supply chain of vegetables (Figure 2). This indicates that, firstly, proactive farmers who take the initiatives, be the first mover in the market, and be a reference for other farmers, tend to have higher orientation towards global supply chains. Their tendency to anticipate future needs (Lumpkin and Dess, 1996) may lead them to take initiatives to reach broader markets (e.g. export markets or modern food retails) beyond the existing markets (e.g. traditional markets). Their initiatives to reach broader markets beyond the existing markets (e.g. traditional markets) may lead them to link with exporters or modern food retails. Secondly, innovative farmers who intensively involve in $\mathrm{R} \& \mathrm{D}$ activities produce new products or improve their farm technologies, tend to involve in global supply chain. It may be because global supply chains provide more suitable outlets for products of innovative farmers in terms of new or improved products. Thirdly, risk taking farmers who are brave in taking high-risk business activities with unknown returns, in achieving goals, and in seeking new opportunities (Shadbolt and Olubode-Awosola, 2016) tend to involve more in global supply chains. chains. New opportunities provided by global supply chains may attract risk taking farmers to fulfill the market needs, such as investing in new technologies. They have positive expectations for the future returns on the investments (Marra et al. 2003). Fourthly, aggressively competitive farmers tend to secure their business by routinely monitoring the business environment, being aggressive over their competitors, and being reactive to the competitors' threats (Lumpkin and Dess, 2001). Their efforts of being better over their competitors can be reflected by involving in global supply chains, which provide more opportunities to be explored. Lastly, autonomous farmers are independent in modifying business, free in making decisions and taking actions, and becoming the knowledge leader (Lumpkin at al. 2009). The tendency to be independent helps the farmers to decide any market they want to access, including markets in the global supply chains. To sum up, dimensions of entrepreneurial orientation facilitate farmers to involve more in global supply chains.

We found that entrepreneurial orientation improves farm performance. In relation to farmer characteristics (Table 1), the farm size is varied largely from thousands meter squares to 50 hectares. Only dimensions of proactiveness and innovativeness improve farm performance. By being proactive, farmers may take the advantage as early adopters to technology, which may provide higher production as one of the indicators of farm performance. Although the previous study found that entrepreneurial orientation improve farm performance in the long run (Grande et al. 2011), we extend their study by proving that entrepreneurial orientation also improves farm performance in the short run.

The results also show that farmers' involvement in global supply chains positively influences farm performance (Figure 1). It indicates that global supply chains may change farmers' orientation from supplydriven farmers to demand-driven farmers. We found that global supply chains give a positive impact on farmers including smallholders, which clarifies the debates on the positive or negative impacts of global supply chains for smallholders. Global supply chains provide positive impacts to smallholders if smallholders produce specific crops for the markets, and if the markets in the global supply chains provide better pricing mechanism for them compared to pricing mechanism of markets in traditional supply chains. Farmers who are engaged 
in the contractual agreement with exporters or modern food retails will be encouraged to produce high quality products, which will be paid by high prices. This may have a positive consequence to farm performance. Hence, farmers who involve in global supply chains may enjoy high farm performance.

\section{Managerial Implication}

This paper proves that entrepreneurial orientation is important for farmers to involve in global supply chain and to improve farm performance. To take benefits from global supply chains, we suggest that farmers should take into account the dimensions of entrepreneurial orientation in their business practices. They may focus on being proactive in anticipating market needs in the future, innovating continuously to satisfy the market needs, carefully managing risks, monitoring routinely the business environment to anticipate competitors' actions, and finally being independent in creating new business activities.

\section{CONCLUSIONS AND RECOMMENDATIONS}

\section{Conclusions}

This paper aims to investigate the impact of entrepreneurial orientation on the farmers' involvement towards global supply chain and farm performance, and in turn the impact farmer involvement in global supply chain on farm performance. The results reveal the important role of entrepreneurial orientation in encouraging farmers to participate in global supply chain and in gaining superior performance. Furthermore, we found that more participation in global supply chain give a positive impact on farm performance. These results are in line with the previous study indicating that entrepreneurial behavior of farmers improves their business performance and the performance of supply chain (Velde et al. 2006). Overall, our study provides an empirical support for the impact of entrepreneurial orientation, not only enabling farmers to access broader markets beyond domestic ones, but also enhancing farm performance.

\section{Recommendations}

We recognize some limitations. This paper does not incorporate either the entire global value chain of vegetables or the roles of other actors, including support providers and policies that enable or hinder the entrepreneurial orientation of farmers, other actors, and the overall value chain performance. We therefore suggest future studies could investigate the potential of the dynamic interactions among the entire components of the value chain and the degree of entrepreneurial orientation and their impact on the overall value chain performance.

Our results show that being entrepreneurial oriented helps farmers to involve in global supply chains, and in turn improves farm performance. We; therefore, recommend policy makers to support farmers to be more entrepreneurial, especially in adapting the market changes. We also suggest policy makers to facilitate farmers to have broader access to global supply chain, such as export markets or modern food retails, by improving farmers' capacity in capturing opportunities and fulfilling these market requirements.

\section{ACKNOWLEDGMENTS}

The authors are grateful for the financial support provided by Ministry of Research, Technology, and Higher Education of the Republic of Indonesia. For their research assistance, the authors would like to thank Rizky Prayogo Ramadhan, Salman Fajri, Muhammad Rizki Mubarok, Febri Hafiyah, Ahmad Syaiful Jamil, Ammar Fathin Mahdi, Taufiq Surahman, Andra Wahyu Widodo, and Khavilana Wifandani Pratama.

\section{REFERENCES}

Amanor KS. 2009. Global food chains, African smallholdersandWorldBankgovernance. Journal of Agrarian Change 9(2):247-262. https://doi. org/10.1111/j.1471-0366.2009.00204.x.

Andersén J. 2010. A critical examination of the EO-performance relationship. International Journal of Entrepreneurial Behaviour and Research 16 (4):309-328. https://doi. org/10.1108/13552551011054507.

Cohen WM, Levinthal DA. 1990. Absortive capacity: A new perspective on learning and innovation. Administrative Science Quarterly 35(1):128152. https://doi.org/10.2307/2393553.

Covin JG, Slevin DP. 1989. Strategic management of small firms in hostile and benign environments. Strategic Management Journal 10(1):75-87. https://doi.org/10.1002/smj.4250100107. 
Dunne AJ. 2001. Supply Chain Management: Fad, panacea or opportunity? Australian Agribusiness Perspectives Paper 48.

Grande J, Madsen EL, Borch OJ. 2011. The relationship between resources, entrepreneurial orientation and performance in farm-based ventures. Entrepreneurship and Regional Development 23(3-4):89-111. https://doi. org/10.1080/08985620903183710.

Hughes M, Morgan RE. 2007. Deconstructing the relationship between entrepreneurial orientation and business performance at the embryonic stage of firm growth. Industrial Marketing Management 36(5):651-661. https://doi. org/10.1016/j.indmarman.2006.04.003.

Kaplinsky R. 2000. Globalisation and unequalisation: What can be learned from value chain analysis? Journal of Development Studies 37(2):117-146. https://doi.org/10.1080/713600071. https://doi. org/10.1080/713600071.

Kaplinsky R. 2004. Spreading the gains from globalization: what can be learned from valuechain analysis?.Problems of Economic Transition 47(2):74-115.

Lumpkin GT, Cogliser CC, Schneider DR. 2009. Understanding and measuring autonomy: An entrepreneurial orientation perspective. Entrepreneurship: Theory and Practice 33(1):47-69.https://doi.org/10.1111/j.15406520.2008.00280.x.

Lumpkin GT, Dess GG. 2001. Linking two dimensions of entrepreneurial orientation to firm performance: The moderating role of environment and industry life cycle. Journal of Business Venturing 16(5):429-451. https://doi.org/10.1016/S08839026(00)00048-3.

Lumpkin GT, Dess GG. 1996. Clarifying the entrepreneurial orientation construct and linking it to performance. Academy of Management Review 21(1):135-172.

Marra M, Pannell DJ, Abadi GA. 2003. The economics of risk, uncertainty and learning in the adoption of new agricultural technologies: where are we on the learning curve? Agricultural Systems 75(2-3):215-234.https://doi.org/10.1016/ S0308-521X(02)00066-5.

Miller D. 1983. The correlates of entrepreneurship in three types of firms. Management Science 29(7):770-791.https://doi.org/10.1287/ mnsc.29.7.770.

Natawidjaja R, Reardon T, Shetty S. 2007. Horticultural
Producers and Supermarket Development In Indonesia. Indonesia: The World Bank.

Riisgaard L, Bolwig S, PonteS, Du Toit A, Halberg N, Matose F. 2010. Integrating poverty and environmental concerns into valuechain analysis: a strategic framework and practical guide. Development Policy Review 28(2):195-216. https://doi.org/10.1111/j.14677679.2010.00481.x.

Sahara S, Gyau A. 2014. Contractual arrangements and commitment in the Indonesian supermarket channel. British Food Journal 116(5):765-779. https://doi.org/10.1108/BFJ-03-2012-0070.

Sanchez G, Trinchera L, Russolillo G. 2017. plspm: Tools for partial least squares path modeling (PLS-PM). cran.r-project.org.

Shadbolt NM, Olubode-Awosola F. 2016. Resilience, risk and entrepreneurship. International Food and Agribusiness Management Review 19(2):3352.

Shalendra KC, Gummagolmath P, Sharma P. 2013. Linking Small and Marginal Farmers to Market for Inclusive Growth. Indian Journal of Agricultural Economics 68(3):496.

Statistics Indonesia. 2014. Berita Resmi Statistik. Jakarta: Statistics Indonesia.

Stevenson HH, Jarillo JC. 2007. A paradigm of entrepreneurship: Entrepreneurial management. In Entrepreneurship 11:17-27.

Sunanto S. 2013. The effect of modern food retail development on consumers, producers, wholesalers and traditional retailers: The case of West Java [dissertation]. Rotterdam: Erasmus University Rotterdam.

Swanson BE. 2006. Seminal article series the changing role of agricultural extension in a global economy. Journal of International Agricultural and Extension Education 13(3): 5-17.

van Dijk MP, Trienekens j. 2011. Global Value Chains: Linking Local Producers from Developing Countries to International Markets, Global Value Chains. Amsterdam: Amsterdam University Press.

Velde DW, Rushton J, Schreckenberg K, Marshall E, Edouard F, Newton A, Arancibia E. 2006. Entrepreneurship in value chains of nontimber forest products. Forest Policy and Economics 8:725-741. https://doi.org/10.1016/j. forpol.2005.06.010.

Verhees FJHM, Lans T, Verstegen JAAM. 2012. The influence of market and entrepreneurial 
orientation on strategic marketing choices: The cases of Dutch farmers and horticultural growers. Journal on Chain and Network Science 12(2):167-179. https://doi.org/10.3920/ JCNS2012.x011.

VonHippelE. 1986. Lead users: a source ofnovel product concepts. Management Science 32(7):791-805. https://doi.org/10.1287/mnsc.32.7.791.

Wiklund J, Shepherd D. 2005. Entrepreneurial orientation and small business performance: A configurational approach. Journal of Business Venturing 20(1):71-91. https://doi.org/10.1016/j. jbusvent.2004.01.001. 